\title{
Estelle Lau, Paper Families. Identity, Immigration Administration and Chinese Exclusion
}

\section{Adam McKeown}

\section{Q OpenEdition}

12 Journals

Édition électronique

URL : http://journals.openedition.org/chinaperspectives/2873

DOI : $10.4000 /$ chinaperspectives.2873

ISSN : 1996-4617

Éditeur

Centre d'étude français sur la Chine contemporaine

Édition imprimée

Date de publication : 15 décembre 2007

ISSN : 2070-3449

Référence électronique

Adam McKeown, « Estelle Lau, Paper Families. Identity, Immigration Administration and Chinese Exclusion», China Perspectives [En ligne], 2007/4 | 2007, mis en ligne le 11 avril 2008, consulté le 21 septembre 2020. URL : http://journals.openedition.org/chinaperspectives/2873 ; DOI : https://doi.org/ 10.4000/chinaperspectives.2873

Ce document a été généré automatiquement le 21 septembre 2020.

(C) All rights reserved 


\title{
Estelle Lau, Paper Families. Identity, Immigration Administration and Chinese Exclusion
}

\author{
Adam McKeown
}

1 The U.S. Chinese exclusion laws enforced from 1882 to 1943 are proving to be a nearly bottomless source of scholarly inspiration. Not only is exclusion one of the substantive and intellectual foundations of Asian American studies and increasingly recognized as a fundamental aspect of U.S. immigration history, but the exclusion archives are a vast repository of diverse sources that will provide sustenance to intrepid and innovative scholars for years to come. Estelle Lau's book adds to the burgeoning literature on the exclusion laws by analysing them in the context of sociological theories about bureaucratic development. Many scholars have noted the crucial role of the Chinese exclusion in forging of U.S. immigration law and as a pioneering institution of the fledgling U.S. administrative state. This is the first work to put questions about administrative (as distinct from the legal) development at the centre of its analysis. Much of the empirical material will be familiar to readers of Asian American history, but Lau's approach brings a new analytical perspective that can create a bridge between Asian American studies, the history of the administrative states, and the sociology of bureaucracy.

Lau sets up the book with several nuanced arguments and questions. She does not want merely to tell an institutional history of how a bureaucracy was established to regulate people, but of how it created the very categories and objects that were to be regulated. The consolidation of exclusion enforcement was not merely a case of the state unilaterally imposing itself upon hapless immigrants, but a set of techniques that emerged through practice. Both regulators and regulated contributed to the creation of procedures that had the capacity to transform a fluid and messy reality into immutable facts and identities. This transformation was ultimately made possible through the establishment of a consistent and uniform procedure that was rooted, above all, in 
textuality as the main indicator of truthfulness. The ability to verify statements was more important than the substance of those statements. Truth was to be found in files.

Unfortunately, the book's empirical exposition does not quite fulfil its ambitious conceptual agenda. The biggest problem is that the sociological method of sampling fails to grasp broader historically processes in which the institutions developed and changed. Given the vastness of the case files, sampling is the only reasonable method of dealing with them. But that sampling must be augmented with a broader knowledge of the overall trajectories of institutional growth, inter-agency politics and historical events. The sampling method does successfully identify a general shift away from apparently arbitrary and unexplained decisions to a system of standardized opinions that could even be written into pre-printed forms. But many of the author's quotes and footnotes are offered without dates, so that much of the material is framed as absolute statements about the exclusion bureaucracy per se rather than as aspects of an historically changing process. For example, some key evidence used to construct arguments about the institutional legacy of exclusion is taken from intra-departmental correspondence in 1905 (especially pp. 141-9). But 1905 was a unique year for the administration of Chinese exclusion, the culmination of seven years of reform that resulted in the anti-American boycott in China, sensationalised criticisms in the press, and deep ruptures within the US government over the proper means of enforcement. None of this is mentioned in the book, but Lau interprets the relatively extreme attitude of the Bureau of Immigration in this correspondence (a position from which it later retreated) as typical of its bureaucratic practice.

4 Lau spends a lot of time on two themes that run parallel to, but are not entirely integrated into, the broader arguments of the introduction. One is an extended discussion of the rise of discretion in the decisions of immigration agents. Not only does the idea of heightened discretion seem to go against evidence from her samples, but it also undermines some of her larger arguments about bureaucratic systematisation. Of course, the two arguments are not incompatible. While specific decisions could be arbitrary, the modes of constructing and justifying those decisions were increasingly formalistic and left a clearly circumscribed space within which discretion could be exercised. Lau hints at this argument in the intro duction (5-6) but does not follow up on it. The other theme is the extended descriptions of how racialised stereotypes shaped immigration decisions. This is not a surprising argument, given that racialisation was written directly into the legislation itself. Indeed, it has been the bread and butter of most previous analyses of the exclusion laws. But such analyses tend to depict exclusion enforcement as a top-down imposition that generated necessary reactions rather than as one of collective agency. Lau follows this line of analysis to argue that the legacy of racism continues to contaminate the entire edifice of immigration law. While this is surely true, a greater integration of the ideas of interactive agency, the creation of procedure through practice, and the importance of textuality would help to create a much more ambivalent picture that also implicates migrants, public opinion, and well-intentioned lawyers as something more than merely reactive agents in the production of this tainted institution.

The final chapter of the book moves beyond 1943 to look at the continuing legacy of the exclusion archives in immigration law and Asian American identity. Lau shows how the files shaped truth and identities during the confession program (of immigration fraud) in the 1950s and 60s, how the files became an anchor of Asian self-knowledge in 
relation to non-Chinese, and how exclusion created a set of general immigration procedures that blames immigrants rather than the system and encourages legalistic trickery over substantive cases. Lau's fairly conventional humanitarian critique of contemporary immigration law does not entirely follow from the arguments about bureaucracy proposed in the introduction. But this book nonetheless suggests a provocative approach to understanding how multiple agents are implicated in the construction of unintended institutions. 